\title{
THE ROLE OF PROBLEM BASED LEARNING ON IMPROVING STUDENTS' MATHEMATICAL CRITICAL THINKING ABILITY AND SELF-REGULATED LEARNING
}

\author{
Musriana Retnaningsih ${ }^{1}$, Asep Ikin Sugandi² \\ ${ }^{1}$ Muhammadiyah Prof. Dr. Hamka University, Jakarta, Indonesia \\ ${ }^{2}$ IKIP Siliwangi, Bandung, Indonesia \\ ${ }^{1}$ musriana.retnaningsih@gmail.com, 2 asepikinsugandi@ gmail.com
}

Received: March, 2018; Accepted: March, 2018

\begin{abstract}
This study is a pre test-post test experimental control group design having a goal to analyze the role of problem based learning on students' mathematical critical thinking ability and self regulated learning. The study involved 60 eighth grade students of an MTs, a mathematical critical thinkng test, and a mathematical self regulated learning scale. The study found that on mathematical critical thinking ability, its gain, and on mathematical self regulated learning, students getting treatment with problem based learning approach attained better grade than that of students taught by conventional teaching. The first group students obtained at fairly good grades level, while the students taught by conventional teaching attained at medium grades level. The other findings, there was fairly good association between mathematical critical thinking ability and mathematical self regulated learning.

Keyword: Mathematical Critical Thinking, Mathematical Self-Regulated Learning, Problem Based Learning
\end{abstract}

\begin{abstract}
Abstrak
Penelitian ini adalah suatu eksperimen berdisain pretes-postes kelompok kontrol, bertujuan menelaah peranan pembelajaran berbasis masalah terhadap kemampuan berpikir kritis dan kemandirian be lajar matematik siswa MTs. Penelitian melibatkan sebanyak 60 siswa kelas delapan, satu set tes berpikir kritis matematik dan satu set skala kemandirian belajar. Penelitian ini menemukan bahwa dalam berpikir kritis , keuntungannya, dan kemandirian belajar matematik, siswa yang mendapat pembelajaran berbasis masalah mencapai mutu yang lebih baik dari pada siswa yang mendapat pembelajaran konvensional. Siswa kelompok pertama mencapai mutu yang cukup baik sedangkan siswa kelompok kedua memperoleh mutu sedang. Selain itu ditemukan pula asosiasi yang cukup antara kemampuan berpikir kritis matematik dan kemandirian belajar.
\end{abstract}

Kata Kunci: Pembelajaran Berbasis Masalah, Kemampuan Berpikir Kritis Matematik, Kemandirian Belajar.

How to Cite: Retnaningsih, M., Sugandi, A, I. (2018). The Role of Problem Based Learning on Improving Students' Mathematical Critical Thinking Ability and Self-Regulated Learning. JIML, 1 (1), 08-17.

\section{INTRODUCTION}

Mathematical critical thinking (MCT) and self regulated learning (SRL) are important mathematical ability and attitude should be improved on high school students. Some reasons which supporting that statement among others are: a) Mathematical critical thinking ability (MCTA) and part of SRL attitude are attached in the goals of mathematics teaching such as students should possess logical, critical, creative, innovative thinking abilities, and possess accurate, objective, opened thinking, self confidence, curious, interest, persevere, persistent 
attitudes (Departemen Pendidikan Nasional, 2013); b) Some experts (Anderson as cited in Lestari, 2013, Peter, 2012, Johnson as cited in Pertiwi, 2011, Lunenburg, 2011) stated the importance of possessing MCTA by students. The statements among other things are: "Student who think critically will tend to evaluate the truth of recieved information and to think self-reliantly" (Anderson, as cited in Lestari 2013; "when a student think critically, mathematical content is transformed into mathematical thinking" (Lunenburg, 2011); "Students who are able to think critically are able to solve problem effectively as well" (Peter, 2012); "Critical thinker tends to behave carefully in taking decision, to confess foolishness fastly, to get new information eagerly, to be patient in investigating a proof, to be tolerant on new viewpoint, and to confess the better viewpoint of other people (Johnson, as cited in Pertiwi, 2011).

Those afformentioned argument ilustrated that MCTA not only support to improve other mathematical abilities but also to promote positive mathematical disposition such as SRL. Based on some experts' opinion (Ennis as cited in Baron and Sternberg (Editors), 1987, Gokhale, 1995) Hendriana, Rohaeti, Sumarmo (2017) elaborate MCTA indicators as follow: a) To focus oneself on a question; b) To analyze, to clarify, to examine the truth of argument or statement, the truth of solution and process of enumeration; c) To consider trusted resources, to identify sufficiency of data; to identify relevant and unrelevant data; d) To deduce, to induce and to analyze them; e) To formulate explanation, hypotesis, and conclusion; f) To interact with other people. To notice those indicators of MCTA, researcher predicts that for executing a MCTA task students need to possess strong a mathematical disposition such as SRL. Bandura (as cited in Sumarmo, 2006) have three main components, namely: to design self-learning objective; to select strategy; to monitor and to evaluate cognitive and affective processes and to compare them to a certain standard.

Based on ideas of some of experts (Butler, Corno and Randi, Hargis, Kerlin, Paris and Winograd, Schunk and Zimmerman, Wongsri, Cantwell, and Archer as cited in Sumarmo, 2006), then Sumarmo (2006) summerize the indicators of SRL such as: a) to possess intrinsic learning initiative and motivation, b) to perform habit to diagnose learning need; c) to determine learning objective and target, d) To monitor, to manage, and to control her or his learning; e) to consider that difficulty as a challenge; f) to use and to seek relevant sources; g) to choice and to apply learning strategy; h) to evaluate learning process and learning outcomes; i) to possess self concept and self efficacy. Yang (as cited in Sumarmo, 2006) finds that students with high SRL: tend to learn better in their own control, are able to control, to evaluate, and to manage their learning effectively, to save their time in solving their tasks, and to manage their time efficiently.

Those a formentioned above strengthens opinion that (MCTA) and SRL should be improved well on high school students. However, some studies (Kurniati, Kusumah, Sabandar, Herman, 2015, Kusnadi, 2016, Sinurat, 2014, Sumarmo, Hidayat, Zulkarnaen, Hamidah, Sariningsih, 2012, Suheri, 2014, Tamsil, 2015, Widyaningtiyas, 2015) found that student's MCTA were still at medium-low level or not conform yet our expectations. This unsatisfying condition motivates researcher to select a certain mathematics teaching approach for improving student's MCTA and SRL accordingly. A kind of mathematics teaching called problem based learning (PBL) has characteristics: a) positioned students as a problem solver through collaborative activities, b) encourage students to solve a non rutine problem; c) to facilitate students to explore various alternative information; d) train students to present their findings, and e) accustom students to reflect their thinking when solving a problem.

Rusman (2010) brings up ten main characteristics of problem based learning, as follow: a) A problem as a starting point in learning; b) The problem is real problem and unstructured; c) The problem needs multi perspective; d) The problem should chalenge student to think; e) Learning self directed is important f) To evaluate information resourses is 
10 Retnaningsih, Sugandi, The Role Of Problem Based Learning On Improving Students' Mathematical Critical Thinking Ability And Self-Regulated Learning

essential in problem based learning; g) Learning collaboratively, communicatively and cooperatively; h) Improving inquiry and problem solving skills are as important as mastering a content well; i) Open situation in synthesizing and integrating; j) Problem based learning involves evaluation and reviews on learning experience and process.

There is different role of a problem in PBL and in conventional teaching. In PBL, first problem is presented in the begining a lesson as a starting point for understanding a concept, then for implementing it on other situation, and then for improving other mathematics abilities as well. In conventional teaching, a problem is presented at end of a lesson as excercises of implementation of concept on a specific and broader situation.

Some of studies with high school students reported the superiority of PBL than conventional teaching on improving MCTA (Noer, 2010, Ibrahim, 2011, Ismaimuza, 2010, Sumarmo, Hidayat, Zulkarnaen, Hamidah, Sariningsih, 2012). Those studies reported that the students taught by PBL attained medium grades level on MCTA and those grades were better than the grades of students taught by conventional teaching. Like that, some studies also reported the supperiority of PBL than conventional teaching on improving students' SRL (Rohaeti, Budiyanto, Sumarmo, 2014, Mashuri, 2012, Mulyana and Hendriana, 2015, Sugandi, 2013).

To observe characteristics of PBL, traits of MCTA and SRL, and some findings of superiority of PBL on improving MCTA and SRL, motivate researchers to carry out a study having goals:

a. To analize the role of PBL on improving students' MCTA and SRL;

b. To analize students' difficulties on solving MCTA;

c. To analize association between MCTA and SRL.

\section{METHOD}

This study is a pretest-posttest control group design having a goal to analize the role of PBL on students' MCTA and SRL. The design of this study is as in the following diagram.

\begin{tabular}{|c|c|c|}
\hline Experiment group & $\mathrm{O}$ & $X$ \\
\hline
\end{tabular}

Notes:

$\mathrm{X}$ : problem-based learning (PBL)

O: pretest and posttest of MCTA test and SRL post-scale

------ : no random sampling

Population of this study are eighth grade students in a MTs in Jakarta and subjects are 60 eighth grade students from two classess selected ramdomly from 6 eighth grade existed classess. The study involves two instruments those are MCTA test anf a SRL scale. The MCTA consists of 6 items which its characteristics as follow: content validity (jugded by conselor- lecturer), item validity (IV); reliability test $\mathrm{r}=0.729$; Discriminat Power (DP) and Difficulty Index (DI); and the SRL scale with reliability $r=0.899$.

The result of IV, DP and DI is shown in the table 1

Table 1. Recapitulation of the Tryout Test MCTA

\begin{tabular}{ccccc}
\hline $\begin{array}{c}\text { Test } \\
\text { number }\end{array}$ & r & DP & DI & Conclusion \\
\hline 1 & 0.410 (Medium) & 0.333 (Enough) & 0.569 (Medium) & Test Item Valid \\
\hline 2 & 0.748 (High) & 0.736 (Very Good) & 0.590 (Medium) & Test Item Valid \\
\hline 3 & 0.553 (Medium) & 0.278 (Enough) & 0.283 (Hard) & Test Item Valid \\
\hline 4 & 0.734 (High) & 0.437 (Good) & 0.463 (Medium) & Test Item Valid \\
\hline
\end{tabular}




\begin{tabular}{lllll}
5 & $0.801($ Very High) & $0.274($ Enough $)$ & $0.241($ Hard $)$ & Test Item Valid \\
\hline 6 & $0.806($ Very High) & $0.326($ Enough $)$ & $0.23($ Hard $)$ & Test Item Valid \\
\hline
\end{tabular}

In the following we attached sample of MCTA and SRL scale.

Sample of MCTA test

1. Fattah and Zain are shoping at the same store. Fattah buys 2 chocolates and 3 candies for Rp.36.000,00. While Zain buy 3 chocolates and 5 candies for Rp.72.000,00. Determine the price of each chocolate and candy ! Check the truth of your answers and explain it.

2. In an office park, there are some cars and motorcycles. Total number of wheels of the vehicles are 210 wheels. The parking cost of a car and a motorcycles are Rp.5.000,00 and Rp.2.000,00 a day consecutively. Number of motorcycles are more than cars. Determine the maximum costs, and accompanied with your reason.

Sample of SRL Scale Items

\begin{tabular}{|c|c|c|c|c|c|}
\hline No. & Statement & $\begin{array}{l}\text { Very } \\
\text { Rarely }\end{array}$ & Rarely & Often & $\begin{array}{l}\text { Very } \\
\text { Often }\end{array}$ \\
\hline 1 & $\begin{array}{l}\text { Ask to a friend or teacher, when face a } \\
\text { difficult problem of Straight Line Equation } \\
\text { and System of Two Linear Equations. }\end{array}$ & & & & \\
\hline 2 & $\begin{array}{l}\text { Feel less prepared when face a test of Straight } \\
\text { Line Equations and System of Two Linear } \\
\text { Equations. }\end{array}$ & & & & \\
\hline 3 & $\begin{array}{l}\text { Try to learn some books for completing a } \\
\text { difficult task of Straight Line Equation and } \\
\text { System of Two Linear Equations. }\end{array}$ & & & & \\
\hline 4 & $\begin{array}{l}\text { Lazy to recheck solution of Straight Line } \\
\text { Equations and System of Two Linear } \\
\text { Equations problem has already done }\end{array}$ & & & & \\
\hline
\end{tabular}

\section{RESULT AND DISCUSSION}

Description of students' MCTA, N Gain of MCTA, and SRL are attached in Table 2.

Table 2. Description of Students' Mathematical Critical Thinking Ability, Mathematical Self Regulated Learning In both Teaching Approaches

\begin{tabular}{|c|c|c|c|c|c|c|c|c|c|}
\hline \multirow[b]{2}{*}{ Variables } & \multirow[b]{2}{*}{ Stat } & \multicolumn{4}{|c|}{ PBL } & \multicolumn{4}{|c|}{ Conventional } \\
\hline & & $\begin{array}{l}\text { Pre- } \\
\text { Test }\end{array}$ & $\begin{array}{c}\text { Post- } \\
\text { Test }\end{array}$ & $\begin{array}{c}\mathbf{N} \\
\text { Gain }\end{array}$ & $\mathbf{N}$ & $\begin{array}{l}\text { Pre- } \\
\text { Test }\end{array}$ & $\begin{array}{l}\text { Post- } \\
\text { Test }\end{array}$ & $\begin{array}{c}\mathbf{N} \\
\text { Gain }\end{array}$ & $\mathbf{N}$ \\
\hline \multirow{3}{*}{ MCTA } & $\bar{X}$ & 10.47 & 38.7 & 0.55 & \multirow{3}{*}{30} & 10.37 & 33.6 & 0.45 & \multirow{3}{*}{30} \\
\hline & $\%$ & 16.88 & 62.47 & & & 16.72 & 54.19 & & \\
\hline & SD & 0.2 & 1.62 & 0.31 & & 0.21 & 1.47 & 0.27 & \\
\hline \multirow{3}{*}{ SRL } & $\bar{X}$ & \multirow{3}{*}{ - } & 86.6 & & \multirow{3}{*}{30} & & 75.83 & \multirow{3}{*}{-} & \multirow{3}{*}{30} \\
\hline & $\%$ & & 67.6 & - & & - & 59.24 & & \\
\hline & SD & & 1.39 & & & & 1.48 & & \\
\hline
\end{tabular}

Note:

MCTA: Mathematical Critical Thinking Ability,

Ideal Score: 62

SRL : Self Regulated Learning Ideal Score: 128 
12 Retnaningsih, Sugandi, The Role Of Problem Based Learning On Improving Students' Mathematical Critical Thinking Ability And Self-Regulated Learning

Based on the data in Table 2, in pretest there was no different grades of students' MCTA in both teaching approaches and both are classified at very low level. But after learning, on MCTA and its Normal Gain, and SRL, students getting treatment with PBL attained better grade than students taught by conventional teaching. However, both students' grades of MCTA were still at low-medium level (62.47\% and $54.19 \%$ out of Ideal Score), both students' N Gain were at medium grade level (0.55 and 0.45), Like that, on SRL first group students obtained at fairly good grade level (67.63\% out of Ideal Score), and second group students attained at medium grade level (59.24\% out of Ideal Score). After testing the normality and homogeneity of relevant data, testing hipothesis of those learning outcomes (postest and postscale) were attached in Tabel 3.

Table 3. Testing Hypothesis of Mean Difference of Mathematical Critical Thinking Ability, And Mathematical Self Regulated Learning on Both Teaching Approaches

\begin{tabular}{|c|c|c|c|c|c|c|c|}
\hline Variables & $\begin{array}{l}\text { Teaching } \\
\text { Approach }\end{array}$ & $\overline{\bar{x}}$ & SD & $\mathbf{n}$ & $\begin{array}{l}\text { Sig(2- } \\
\text { tailed). }\end{array}$ & $\begin{array}{l}\text { Sig(1- } \\
\text { tailed). }\end{array}$ & Interpretation \\
\hline \multirow[b]{2}{*}{ MCTA } & PBL & 38.73 & 1.62 & 30 & \multirow[t]{2}{*}{.022} & \multirow[t]{2}{*}{$.011<.05$} & \multirow[t]{2}{*}{ MCTA $\mathrm{PBL}>\mathrm{MCTACT}$} \\
\hline & $\mathrm{CT}$ & 33.60 & 1.47 & 30 & & & \\
\hline \multirow{2}{*}{$\begin{array}{l}\text { N-Gain } \\
\text { MCTA }\end{array}$} & PBL & .55 & .31 & 30 & \multirow[t]{2}{*}{.020} & \multirow[t]{2}{*}{$.010<.05$} & \multirow{2}{*}{$\begin{array}{l}\text { N-Gain MCTA } \text { PBL }^{>} \\
\text {N-Gain MCTA }{ }_{C T}\end{array}$} \\
\hline & $\mathrm{CT}$ & .45 & .27 & 30 & & & \\
\hline \multirow[b]{2}{*}{ SRL } & PBL & 86.57 & 1.39 & 30 & \multirow[t]{2}{*}{.000} & \multirow[t]{2}{*}{$.000<.05$} & \multirow[t]{2}{*}{ SRL PBL $>$ SRLCT } \\
\hline & CT & 75.83 & 1.48 & 30 & & & \\
\hline
\end{tabular}

Note: MCTA: Mathematical Critical Thinking Ability SRL : Self Regulated Learning Ideal Score: 128

Findings on students' MCTA of this study were similar to findings of other previous studies (Jumaisyaroh, Napitupulu, Hasratuddin, 2014, Kurniati, Kusumah, Sabandar, Herman, 2015, Kusnadi, 2016, Sinurat, 2014, Sumarmo, et.all, 2012, Suheri, 2014, Tamsil, 2015 Widyaningtiyas, 2015) which found that students' MCTA were still at medium-low level or not conform yet to our expectations. However, findings on SRL that was at mediumfairly good grade level of this study was rather different with findings other studies such as (Aminah, 2016, Jumaisyaroh, et.all, 2014, Mulyana and Hendriana, 2015, Qohar and Sumarmo, 2014, Rohaeti, Budiyanto, Sumarmo, 2014, Setiawati, 2014, Sumarni and Sumarmo 2017) that on SRL students obtained at fairly good grade level. Findings of students' difficulties on solving MCTA test were attached in Table 4.

Table 4. Mean Score Of Each Item Of Mathematical Critical Thinking Test of Students In Both Teaching Approaches

\begin{tabular}{|c|c|c|c|c|c|c|c|c|}
\hline \multirow{2}{*}{$\begin{array}{l}\text { Teaching } \\
\text { approach }\end{array}$} & Stat.Desc & No.1 & No 2. & No.3 & No.4 & No.5 & No.6 & Entirely \\
\hline & $\begin{array}{l}\text { Ideal } \\
\text { score }\end{array}$ & 8 & 8 & 10 & 12 & 12 & 12 & 62 \\
\hline \multirow{2}{*}{$\begin{array}{l}\text { Problem Based } \\
\text { Learning (PBL) }\end{array}$} & $\bar{x}$ & 6.57 & 6.83 & 4.83 & 10.33 & 4.83 & 5.33 & 38.73 \\
\hline & $\%$ of IS & 82.08 & 85.42 & 48.33 & 86.11 & 40.28 & 44.44 & 62.47 \\
\hline \multirow{2}{*}{$\begin{array}{l}\text { Conventional } \\
\text { Teaching }\end{array}$} & $\bar{x}$ & 5.77 & 4.77 & 4.90 & 9.67 & 3.67 & 4.83 & 33.6 \\
\hline & $\%$ of IS & 72.08 & 59.58 & 49.00 & 80.56 & 30.56 & 40.28 & 54.19 \\
\hline
\end{tabular}


Based on the data in Table 4, students face difficulties in item numbers 3.5 and 6 which scores less than $60 \%$ of the ideal score of 48.33 ; 40.28 ; and 44.44 in the PBL and 49 ; 30.56; and 40.28 in the conventional teaching.

Finding of this study on students' MCTA that was at low-medium grade level illustrated that MCTA test was still as difficult mathematics task. From Table 4, it were found that students faced difficulties on solving MCTA items no. 3.5 and 6 that is about checking the truth of a given revelation and then solving it and composing answers or solving mathematical problems with the reasons. This is because students are not able to analyze and evaluate an information in a matter that berbetuk matter non routine story logically, accurately, broadly, deeply. Students are also less able to express a clear argument. To overcome those students' difficulties teacher should be examined first students' understading on the prerequisite of mathematics content will be taught. When students' mastering of that prerequisite content were still low so teacher should carry out remedial teaching and then gave various non-rutine and different level of difficulties mathematical critical problems, from relative easier and increase to more difficult gradually. Beside that, for reaching better meaningfull mathematical understanding, it was suggested to ask students to write mathematical rules, or concept that involved in each step of enumeration.

After teaching-learning process, students' SRL were still at medium-fairly good grade level. This finding actually was rational, caused of for improving SRL or other affective learning outcomes such as value and charachter education it need longer time. It was different with improving certain mathematical ability. Refering to Sauri's opinion (2010), students' SRL can be improved through four ways namely: a) Be aware of students to the importance of having mathematical SRL; b) teacher should perform having behavior as wished in mathematical SRL, c) students should be accustomized having behavior as wished in mathematical SRL; and d) teacher should carry out integrated and continous mathematics teaching process.

Finding about association between MCTA and SRL was determined by using Table Contigency as in Table 5

Table 5. Number of Students Based on the criteria of High, Medium and Low Critical Thinking Ability and Self-Regulated Learning on PBL Class

\begin{tabular}{lllll}
\hline Critical Thinking & High & Medium & Low & Total \\
\hline High & 4 & 1 & 0 & 5 \\
Medium & 4 & 8 & 0 & 12 \\
Low & 0 & 11 & 2 & 13 \\
Total & 8 & 20 & 2 & 30 \\
\hline
\end{tabular}

Then the chi-square test using SPSS 16 obtained by use values Sig $=0.008$. Because both groups sig $<\alpha=0.05, \mathrm{H}_{0}$ is rejected. This means that there is a significant association between MCTA and SRL of with contingency coefficient $C=0.562$. It was meant there was fairly strong association between MCTA and SRL. This finding was similar to other previous studies findings (Jayadipura, 2014, Qohar, and Sumarmo, 2014, Tamsil, 2015) that there were association between MCTA with various affective mathematics learning outcomes. But, those findings was different with some other studies (Sinurat, 2014, Sumarmo, et al, 2012, Widyaningtyas, 2015) that there were no association between MCTA with various affective mathematics learning outcomes. Those findings indicated that there were incosistent findings on the existency of association between MCTA and various affective mathematics learning outcomes. 
14 Retnaningsih, Sugandi, The Role Of Problem Based Learning On Improving Students' Mathematical Critical Thinking Ability And Self-Regulated Learning

In this study, despite students' grades on MCTA and on SRL in both teaching approaches still at low-medium grades level, but students getting treatment with PBL performed more active in learning and solving problems in Student Work Sheet compare to students activities in conventional teaching class such as in the following figures.

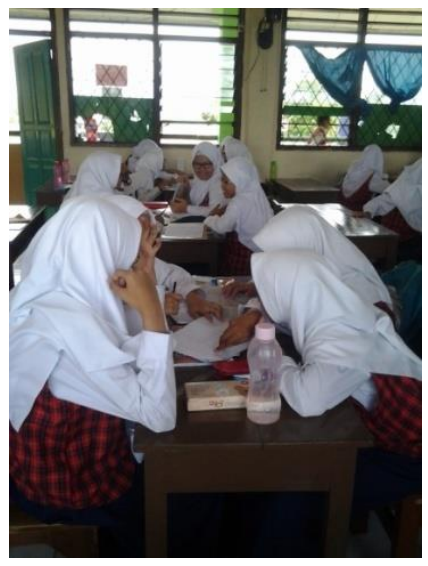

Figure 1, in PBL class. Students were given real questions then discussed in the group

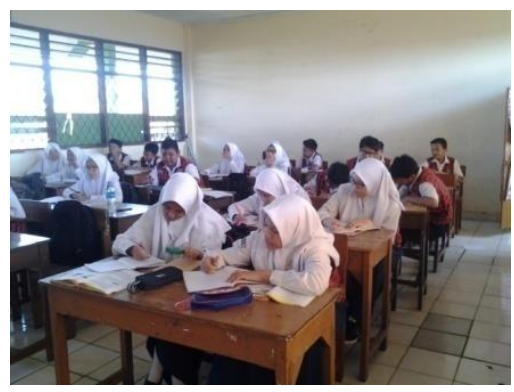

Figure 4. In CT class.

Students listened to the teacher's explanation and then recorded it in a notebook.

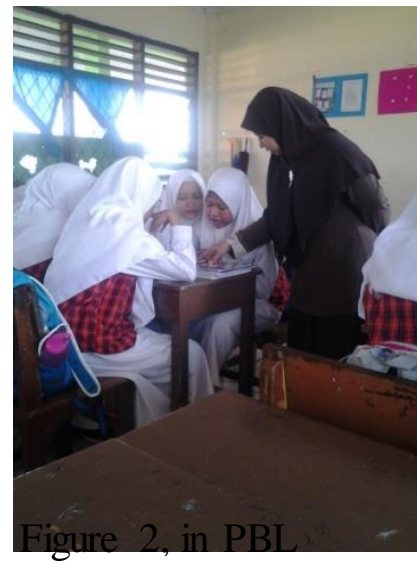

class.Teachers provide scaffolding to students about the difficulties students experience independently or in groups in class.

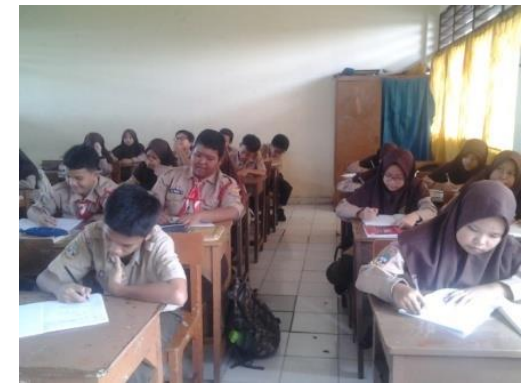

Figure 5. In CT class. Students do the exercises given by teachers.

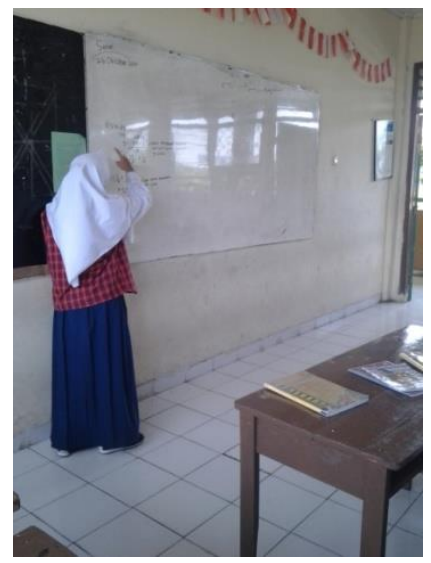

Figure 3, in PBL class. One student presents the solution of a problem in front of the class

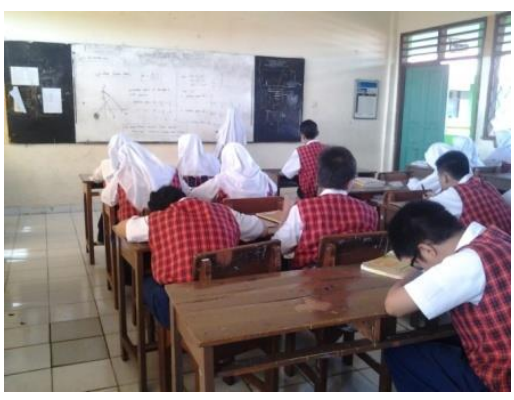

Figure 6. In CT class. Students explain answers to the exercise questions in front of the class.

\section{CONCLUSION}

Based on the findings and discussion, this study derived some conclusions as follow. Problem-based learning took better role than conventional teaching on obtaining and gaining students' MCTA, and on attaining students' SRL. However in both teaching approaches students' MCTA were still at low grade level, students still realized some difficulties on solving MCTA problems namely on about checking the truth of a given revelation and then solving it and composing answers or solving mathematical problems with the reasons.Other conclusion of this study were: on SRL, students getting treatment with PBL attained fairly good grade level, and students taught by conventional obtained SRL at medium grade level; and there was fairly good assocation between MCTA and SRL. Beside that, students getting 
treatment with PBL performed more active learning and solving mathematical problem on Students' Work-Sheet.

For improving better students' MCTA, it is suggested to examine fisrt students' mastering on prerequisite of mathematics content that will be learned, and motivate students to solve various level of problem difficulties. Like that, for reaching better meaningful mathematical critical thinking and understanding, ask students to write mathematics rules or principles that they used in each step of mathematics enumeration. Beside that, for improving better students' SRL, it was suggested four ways as follow: a) Be aware students to the importance of having mathematical SRL; b) Teacher should perform having behavior as wished in mathematical SRL, c) Students should be accustomized having behavior as wished in mathematical SRL; and d) Teacher should carry out integrated and continous mathematics teaching process.

\section{REFERENCES}

Aminah, M. (2016). Mengembangkan Kemampuan Berpikir Logis, Komunikasi dan Kemandirian Belajar Matematis Siswa SMA melalui Pembelajaran Metakognitif. Disertation at Post Graduate Study of Indonesia University of Education. Part of disertation was submitted to publish in International Journal of Instruction. http://www.e-iji.net (in progress)

Baron, J. B. dan Sternberg, R.J. (Editor), (1987) Teaching Thinking Skill. New York: W.H. Freeman and Company

Departemen Pendidikan Nasional (2013). Peraturan Menteri Pendidikan dan Kebudayaan Republik Indonesia Nomor 81A Tahun 2013, tentang Implementasi Kurikulum, 2013.

Gokhale, A. A. (1995). Collaborative Learning Enhances Critical Thinking. [Online]. http://Scholer.lib.vt.edu./ejournals/JTEI V7 n1/pdf/Gokhale.pdf.

Hendriana, H., Rohaeti, E.E., Sumarmo, U. (2017). Hard Skill dan Soft Skill Matematis Siswa. Bandung: Penerbit PT Refika Aditama.

Ibrahim, (2011). Pengembangan Kemampuan Berpikir Kritis dan Kreatif Matematis Siswa Melalui Pembelajaran Berbasis-Masalah Yang Menghadirkan Kecerdasan Emosional. Prosiding Seminar Nasional Matematika dan Pendidikan Matematika. Yogyakarta: UNY, 3 Desember 2011.

Ismaimuza, D. (2010). Kemampuan Berpikir Kritis dan Kreatif Matematik Siswa SMP Melalui Pembelajaran Berbasis Masalah dengan Strategi Konflik Kognitif. Unpublished Disertaion at Postgraduate UPI. Bandung.

Jayadipura, Y. (2014). Mengembangkan Kemampuan Berpikir Kritis dan Kreatif Matematis serta Kemandirian Belajar Siswa SMA melalui Pembelajaran Kontekstual. Unpublished Thesis at Post Graduate Study of STKIP Siliwangi Bandung.

Jumaisyaroh. T, Napitupulu. EE, Hasratuddin. (2014). Peningkatan Kemampuan Berpikir Kritis Matematis Dan Kemandirian Belajar Siswa Smp Melalui Pembelajaran Berbasis Masalah. J. Kreano. 5(2):157-169, https://journal.unnes.ac.id/artikel_nju/kreano/3325

Kurniati, Kusumah, Y.S, Sabandar, Y. Herman, T. (2015). "Mathematical Critical Thinking Ability through Contextual Teaching and Learning Approach". J. Journal on Mathematics Education (IndoMS-JME).6(1): https://ejournal.unsri.ac.id/index.php/jme/article/view/1901/796

Kusnadi.A. (2016). Peningkatan Komunikasi dan Berpikir Kritis Serta Disposisi Matematik Siswa SMK Melalui Pendekatan Saintifik. Unpublished Thesis. STKIP Siliwangi. Bandung.

Lestari, K.E. (2013). Implementasi BRAIN-BASED LEARNING untuk Meningkatkan Kemampuan Koneksi dan kemampuan berpikir kritis Matematis Siswa Sekolah 
16 Retnaningsih, Sugandi, The Role Of Problem Based Learning On Improving Students' Mathematical Critical Thinking Ability And Self-Regulated Learning

Menengah Pertama. J. Jurnal Pendidikan Unsika. 2(1): https://journal.unsika.ac.id/index.php/judika/article/view/120.

Lunenburg, F.C. (2011). "Critical Thinking and Constructivism Techniques for Improving Student Achievement" Paper published in National Forum Teacher Education Journal.21,(3), 1-9.

Mashuri, I. (2012). Pengaruh Pembelajaran Berbasis Masalah dan Inkuiri ditinjau dari Kemandirian Belajar Siswa Kelas X Sma Negeri Kabupaten Blora. J. JMEE. 2(1): 1935. http://www.jurnal.fkip.uns.ac.id/index.php/jmme/article/view/9079.

Mulyana, A. and Hendriana, H. (2015). "Meningkatkan Kemampuan Penalaran Matematik dan Kemandirian Belajar Siswa SMP melalui Pembelajaran Berbasis Masalah". J. Edusentris, Jurnal Ilmu Pendidikan dan Pengajaran, 9(1). July 2015. http://ejournal.stkipsiliwangi.ac.id/index.php/didaktik/article/view/116

Noer, S. H. (2010). Peningkatan Kemampuan Berpikir Kritis, Kreatif, Dan Reflektif (K2R) Matematik Siswa SMP Melalui Pembelajaran Berbasis Masalah. Unpublished Disertaion at Postgraduate UPI. Bandung

Peter, E.E. (2012). "Critical Thinking: Essence for Teaching Mathematics and Mathematics Problem Solving Skills”. J. African Journal of Mathematics and Computer Science Research. 5, (93): 39-43. http://www.academicjournals.org/journal/AJMCSR/articleabstract/AD35F3D4458

Pertiwi, N. (2011). Pengaruh Metode Kooperatif Strategi The Power of Two terhadap Kemampuan Berpikir Kritis Siswa SMP dalam Pembelajaran Matematika. Unpublished Thesis at Undergraduate FPMIPA UPI. Bandung.

Qohar, A., \& Sumarmo, U. (2014). "Improving Mathematical Communication Ability and Self Regulated Learning Of Yunior High Students by Using Reciprocal Teaching" $J$. $\begin{array}{llll}\text { Journal on } & \text { Mathematics }\end{array}$ https://ejournal.unsri.ac.id/index.php/jme/article/view/562

Rohaeti, E.E. Budiyanto, A.M., Sumarmo, U (2014). "Enhancing Mathematical Logical Thinking Ability and Self Regulated Learning of Students through Problem Based Learning". J. International Journal of Education .8(1): 54-63. http://ejournal.upi.edu/index.php/ije/article/view/1768.

Rusman, (2010), Model-Model Pembelajaran. Bandung: Mulya Mandiri Pers.

Sauri, S. (2010). Membangun Karakter Bangsa melalui Pembinaan Profesionalisme Guru Berbasis Pendidikan Nilai. J. Jurnal Pendidikan Karakter. 2(2). http://file.upi.edu/Direktori/FPBS/JUR._PEND._BAHASA_ARAB/195604201983011SOFYAN_SAURI/presentasi2/MEMBANGUN_KARAKTER_[Compatibility_Mode]. pdf.

Setiawati, E. (2014). Mengembangkan kemampuan berpikir logis, kreatif, dan self regulated learning matematis, siswa SMA melalui Pembelajaran Berbasis Masalah. Unpublished Disertation at Post Graduate Study of Indonesia University of Education.

Sinurat, R. (2014). Meningkatkan Kemampuan Berpikir Kritis dan Kreatif serta Disposisi Matematik Siswa SMA melalui Pembelajaran Kontekstual. Unpublished Thes is at Post Graduate Study of STKIP Siliwangi, Bandung.

Sugandi, AI. (2013). Pengaruh Pembelajaran Berbasis Masalah dengan Setting Kooperatif Jigsaw Terhadap Kemandirian Belajar Siswa SMA. J. Infinity. 2(2): 144-155. http://ejournal.stkipsiliwangi.ac.id/index.php/infinity/article/view/31.

Suheri. (2014).Kemampuan Berpikir Kreatif dan Berpikir Kritis Serta Disposisi Matematik Siswa SMP Dalam Pembelajaran Kontekstual Model Cooperative Learning. Unpublished Thesis at Post Graduate Study of STKIP Siliwangi, Bandung. 
Sumarmo, U, Hidayat, W., Zulkarnaen, R, Hamidah, Sariningsih, R. (2012). Mengembangkan Kemampuan dan Disposisi Berpikir Logis, Kritis, dan Kreatif Matematis Siswa SMA melalui Pembelajaran Berbasis Masalah dan Strategi Think-Talk-Write. J. Jurnal Pengajaran MIPA,

17(1):17-33, http://journal.fpmipa.upi.edu/ind ex.php/jpmipa/article/view/228

Sumarmo, U. (2006). Kemandirian Belajar: Apa, Mengapa Dan Bagaimana Dikembangkan pada Peserta Didik. Paper presented at National Seminar of Mathematics Education at State University of Yogayakarta in 2006. Paper was completed as learning material of the course of Global Issue and review of Indonesia, Posgraduate Program of Indonesia University of Education. February 2011.

Sumarni, C. and Sumarmo, U. (2017). Penalaran Matematik dan Kemandirian Belajar: Eksperimen terhadap Siswa SMP melalui Pembelajaran Generatif. J. Edusentris: Jurnal Ilmu Pendidikan dan Pengajaran. 3 (1): 290-299, http://ejournal.sps.upi.edu/index.php/edusentris/article/view/239

Tamsil, S. (2015). Meningkatkan Kemampuan Berpikir Kritis dan Kreatif Matematik Serta Kepercayaan Diri Siswa SMA Melalui Pembelajaran Langsung-Tak Langsung. Unpublished Thesis at Post Graduate Study of STKIP Siliwangi, Bandung.

Widyaningtiyas, R. (2015). Pengaruh Pendekatan Pembelajaran Berbasis Masalah terhadap Kemampuan dan Disposisi Berpikir Kritis dan Kreatif Matematis Siswa SMA. Unpublished Disertation at Post Graduate Study of Indonesia University of Education. 